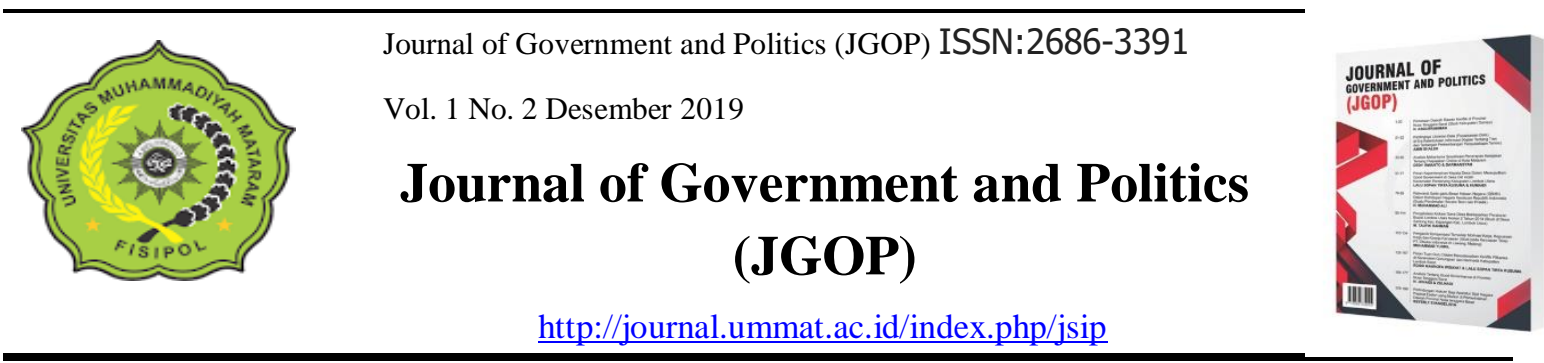

\title{
Peran Dinas Pemberdayaan Perempuan Dan Perlindungan Anak Dalam Menangani Kekerasan Terhadap Perempuan
}

\author{
Baiq Lia Hardiani ${ }^{1}$ Ayatullah Hadi ${ }^{2}$ Iskandar $^{3}$ \\ ${ }^{123}$ Universitas Muhammadiyah Mataram
}

InfoArtikel

Sejarah Artikel:

Diterima: 16 Oktober 2019

Disetujui: 20 Desember 2019

Dipublikasikan : 20

Desember 2019

Kata Kunci :

Peran; Dinas

Pemberdayaan

Perempuan; KDRT

\section{Abstrak}

Kekerasan di dalam rumah tangga (KDRT) merupakan bentuk kekerasan terhadap perempuan yang insidennya paling tinggi, dan dapat berbentuk fisik, psikis maupun ekonomi. Di dalam kategori kekerasan seksual, yang paling banyak adalah perkosaan, termasuk perkosaan di dalam perkawinan, yang sejak 2004 diakui di dalam pasal 8a UU Penghapusan Kekerasan Dalam Rumah Tangga (UU PKKDRT no. 23/2004). Meski jelas adanya UU KPKDRT no. 23/2004 merupakan kemajuan besar, namun penerapannya masih menemui banyak tantangan. Ini karena faktor kultural dan struktural yang begitu kokoh, saling melengkapi dan merasuk di dalam sanubari masyarakat Indonesia, baik secara individual maupun institusional.

Penelitian ini bertujuan untuk menganalisis peran Dinas Pemberdayaan Perempuan dan Perlindungan Anak Dalam Menangani Kekerasan Terhadap Perempuan di Kabupaten Lombok Tengah dan faktor penghambat peran Dinas Pemberdayaan Perempuan dan Perlindungan Anak Dalam Menangani Kekerasan Terhadap Perempuan di Kabupaten Lombok Tengah. Hasil penelitian ini ditemukan bahwa Peran Dinas Pemberdayaan Perempuan dan Perlindungan Anak Dalam Menangani Kekerasan Terhadap Perempuan di Kabupaten Lombok Tengah Dinas Pemberdayaan Perempuan dan Perlindungan Anak Kabupaten Lombok Tengah melaksanakan peran sesuai dengan tugas pokok dan fungsi serta kewenangannya berdasarkan peraturan yang berlaku salahsatunya memberikan pendampingan, semangat dan saran kepada korban tindak kekerasan fisik dan psikologis. Dinas Pemberdayaan Perempuan dan Perlindungan Anak Kabupaten Lombok Tengah juga memberikan saran-saran dan solusi agar kejadian tindakan kekerasan terhadap perempuan tidak terulang kembali. 
Journal of Government and Politics (JGOP) Vol. 1 No. 2 Desember 2019 Hal. 112-124

The Role Of The Department Of Women Empowerment And Children Protection

In Handling Violence Against Women In Central Lombok District In 2018

Abstract

Domestic violence is the highest form of violence against women, and can be physical, psychological or economic. In the category of sexual violence, the most is rape, including marital rape, which since 2004 has been recognized in article $8 a$ of the Law on the Elimination of Domestic Violence (PKKDRT Law no. 23/2004). Although it is clear that the KPKDRT Law no. 23/2004 is a big progress, but its implementation still faces many challenges. This is because cultural and structural factors are so solid, complementary and pervasive in the heart of Indonesian society, both individually and institutionally.

This study aims to analyze the role of the Office of Women's Empowerment and Child Protection in Dealing with Violence Against Women in Central Lombok District and the inhibiting factors of the Office of Women's Empowerment and Child Protection in Addressing Violence Against Women in Central Lombok District. The results of this study found that the Role of the Women's Empowerment Office and Child Protection in Dealing with Violence Against Women in Central Lombok District, the Central Lombok Women's Empowerment and Child Protection Agency carried out the role in accordance with the main tasks and functions and authorities based on the applicable regulations. advice to victims of physical and psychological violence. The Central Lombok District Women's Empowerment and Child Protection Agency also provides suggestions and solutions so that the occurrence of acts of violence against women does not recur. 


\section{PENDAHULUAN}

Kekerasan merupakan isu utama di seluruh Dunia, baik di Negara maju maupun Negara berkembang seperti di Indonesia, memperbincangkan tindak kekerasan terhadap perempuan yang belakangan ini marak terjadi dimana-mana, hal ini beralasan, karena ternyata kekerasan merupakan suatu bentuk manifestasi perilaku emosionalnya manusia, ketimbang perilaku rasionalnya, saat ini dimanamana banyak dihadapi berbagai kasus tindak kekerasan yang korbannya adalah perempuan. Menjadi persoalan bagi kita semua sejauh mana kita semua ikut bertanggung jawab dan berperan serta untuk mencari solusi pemecahan masalah ini.

Komnas Perempuan menunjukkan pada tahun 2016 terdapat hampir 260.000 jumlah insiden Kekerasan Terhadap Perempuan (TKP). Sebagian data ini diperoleh dari 359 pengadilan agama, sebagian dari 233 lembaga mitra pengada layanan yang terdapat di 34 provinsi di Indonesia. Angka-angka Kekerasan Terhadap Perempuan, dan juga kekerasan terhadap anak, sudah bisa dikatakan tinggi, dan cenderung meningkat setiap tahun. Namun Indraswari, Ketua Subkomisi Pemantauan Komnas Perempuan, mensinyalir bawa angka-angka ini hanya merupakan puncak gunung es.

Meski jelas adanya UU KPKDRT no. 23/2004 merupakan kemajuan besar, namun penerapannya masih menemui banyak tantangan. Ini karena faktor kultural dan struktural yang begitu kokoh, saling melengkapi dan merasuk di dalam sanubari masyarakat Indonesia, baik secara individual maupun institusional. Diperlukan upaya perlindungan yang harus terus dilakukan demi menghapuskan diskriminasi dan ketidakadilan gender terhadap perempuan.Secara prinsip, perbedaan gender bukanlah suatu permasalahan namun hal itu bisa menjadi masalah ketika perbedaan tersebut mendorong terjadinya ketidakadilan gender, yaitu suatu kondisi dimana muncul ketidaksetaraan hak dan kewajiban yang dimiliki antara laki-laki dan perempuan. Pertanda bahwa terjadi ketidakadilan gender adalah adanya diskriminasi terhadap perempuan.

Kabupaten Lombok Tengah adalah salah satu Kabupaten yang ada di Nusa Tenggara Barat yang juga memiliki peran penting untuk mengurangi terjadinya kekerasan terhadap perempuan. Salahsatu bentuk dan wujud nyata dari kinerja pemerintah daerah Kabupaten Lombok Tengah untuk mengurangi terjadinya kekerasan terhadap perempuan dan anak, dengan membentuk Dinas Pemberdayaan Perempuan dan Perlindungan Anak (DP2PA) Kabupaten Lombok Tengah. 
Salah satu masalah yang menjadi sorotan masyarakat Kabupaten Lombok Tengah Provinsi Nusa Tenggara Barat saat ini adalah mengenai kekerasan perempuan di Kabupaten Lombok Tengah. Masalah ini memiliki arti penting dalam kegiatan penanganan dan pencegahan dalam menyelesaikan masalah kekerasan yang terjadi di Kabupaten Lombok Tengah. Dinas Pemberdayaan Perempuan dan Perlindungan Anak (DP2PA) Kabupaten Lombok Tengah merupakan model penyelenggaraan kegiatan penerapan kebijakan, pembinaan, pengawasan, peningkatan, pelaksanaan pelayanan yang searah dengan kebijakan umum Daerah dan merujuk kepada bebijakan umum nasional serta kebijakan Daerah Provinsi. Dengan tujuan sebagai berikut, terwujudnya peningkatan kualitas dan kinerja SDM dan disiplin aparatur, terwujudnya peningkatan peranan serta partisipasi masyarakat, terwujudnya peningkatan kesejahteraan hidup masyarakat, terwujudnya peningkatan pemberdayaan masyarakat dan taraf kesejahteraan hidup masyarakat.

Berdasarkan dalam pencatatan korban kasus kekerasan terhadap perempuan disini dikategorikan kekerasan terhadap perempuan ialah dengan usia 18 tahun keatas itu sudah termasuk dalam kategori kekerasan terhadap perempuan bukan kekerasan terhadap anak untuk memisahkan bentuk kekerasan terhadap anak dengan kekerasan terhadap perempuan yang sudah di atur dalam aturan dari Kementrian perlindungan perempuan dan perlindungan anak.

Dengan adanya Dinas Pemberdayaan Perempuan dan Perlindungan Anak (DP2PA) dengan maksud ingin memberikan bantuan dalam menangani kasus kekerasan yang terjadi terhadap perempuan kepada masyarakat yang membutuhkan bantuan penangan kasus kekerasan yang dialami. Bentuk bantuan penanganan yang diberikan oleh DP2PA yaitu adalah sebagai berikut, seperti menjadi Fasilitator, Konselor, Mediator, dan bantuan Advokator bagi para korban yang membutuhkan bantuan. Berdasarkan fenomena menunjukkan bahwa penanganan dalam kekerasan perempuan belum menunjukan sebuah kemajuan peran dari Dinas Pemberdayaan Perempuan dan Perlindungan Anak Kabupaten Lombok Tengah untuk menangani kekerasan terhadap perempuan untuk melakukan Fasilitator, Konselor, Mediator, dan bantuan Advokator belum menunjukan perkembangan perbaikan dan pencegahan serta memberantas tindak kekerasan terhadap perempuan.

Melihat dari indikasi dilapangan, maka sebagai langkah kebijakan untuk dapat meningkatkan kualitas penanganan, dalam rangka mensukseskan program perlindungan perempuan, maka sudah sewajarnya Dinas Pemberdayaan Perempuan dan Perlindungan Anak mengoptimalkan kinerjanya, sehingga hasil yang dicapai akan semakin baik. Mengingat luasnya cakupan mengenai kekerasan perempuan maka ruang lingkup penelitian dalam 
penelitian ini adalah Peran Dinas Pemberdayaan Perempuan dan Perlindungan Anak di bidang Perlindungan Hak Perempuan dan Perlindungan Khusus anak Peran dari Dinas dalam menangani kekerasan terhadap perempuan yang difokuskan pada Kabupaten Lombok Tengah.

Sehubungan dengan hal tersebut, maka penulis tertarik untuk melakukan penelitian untuk membahas masalah Kekerasan Terhadap Perempuan demimeningkatkan pelayanan dalam menangani kekerasan perempuan dengan mengambil judul penelitian: "Peran Dinas Pemberdayaan Perempuan dan Perlindungan Anak Dalam Menangani Kekerasan Terhadap Perempuan di Kabupaten Lombok Tengah Provinsi Nusa Tenggara Barat”.

\section{METODE PENELITIAN}

Penelitian ini tergolong pada tipe penelitian deskriptif dengan pendekatan kualitatif. Menurut Moleong (2011:6) penelitian kualitatif bermaksud untuk memahami fenomena tentang apa yang dialami oleh subyek penelitian misalnya, perilaku, persepsi, motivasi, tindakan, dll secara holistik, dan dengan cara deskriptif dalam bentuk kata-kata dan bahasa pada suatu konteks khusus yang alamiah dan dengan memanfaatkan berbagai metode ilmiah.

Pengumpulan data dilakukan dengan teknis observasi, wawancara, dan dokumentasi. Teknis analisis data yang digunakan meliputi pengumpulan data, reduksi data, penyajian data, kemudian menarik kesimpulan. Keabsahan data yang digunakan adalah teknis triangulasi sumber.

\section{HASIL DAN PEMBAHASAN}

Peran Dinas Pemberdayaan Perempuan dan Perlindungan Anak Kabupaten Lombok Tengah dalam Menangani Kekerasan Terhadap Perempuan di Kabupaten Lombok Tengah

Berdasarkan tugas pokok dan fungsinya Dinas Pemberdayaan Perempuan dan Perlindungan Anak Kabupaten Lombok Tengah harus menjalankan fungsinya sebagai fasilitator dimana fasilitator adalah sekelompok orang yang mendampingi, memberi semangat, pengetahuan, bantuan, saran, suatu kelompok dalam memecahkan masalah sehingga kelompok lebih maju (Nn, 2007:1). Filosofi dari fasilitator adalah adanya suatu kelompok yang memiliki tujuan, rencana, gagasan, program, sarana dalam melaksanakan kegiatan dalam memecahkan masalah yang dihadapi secara bersama-sama. Fasilitasi akan (selalu) berkenaan dengan kelompok. Fasilitasi adalah sebuah proses dimana seseorang yang dapat diterima oleh seluruh 
anggota kelompok, secara substantif berdiri netral, dan tidak punya otoritas mengambil kebijakan, melakukan intervensi untuk membantu kelompok memperbaiki cara-cara mengidentifikasi dan menyelesaikan berbagai masalah, serta membuat keputusan, agar bisa meningkatkan efektivitas kelompok itu (Roger M. Schwarz, 1994: 4). "Intervensi” berarti masuk ke wilayah sistem yang sudah berjalan untuk sebuah upaya membantu mereka yang berada dalam sistem.

Pemberian fasilitator dalam bentuk pendampingan, saran, semangat dan bantuan oleh Dinas Pemberdayaan perempuan dan perlindungan anak di Kabupaten Lombok Tengah pada perempuan yang mengalami tindakan kekerasan dalam dalam rumah tangga dan lain sebagainya. Kepala Dinas Pemberdayaan Perempuan dan Perlindungan Anak Kabupaten Lombok Tengah menyampaikan bahwa: "Peran Dinas Pemberdayaan Perempuan dan Perlindungan Anak Kabupaten Lombok Tengah salahsatunya adalah memberikan pendampingan, semangat dan saran kepada korban agar tidak terjadinya trauma yang mendalam dan berkepanjangan pada korban. Dalam hal ini kami akan memberikan bimbingan psikologis juga agar korban bisa melanjutkan hidup dengan baik. Selanjutnya kami juga memberikan saran-saran terbaik agar mendapatkan jalan keluar. Sehingga kedepannya tidak lagi terjadi kekerasan fisik pada perempuan”

Dari data yang diperoleh dilapangan dapat diketahui bahwa Dinas Pemberdayaan Perempuan dan Perlindungan Anak Kabupaten Lombok Tengah melaksanakan peran sesuai dengan tugas pokok dan fungsi serta kewenangannya berdasarkan peraturan yang berlaku salahsatunya memberikan pendampingan, semangat dan saran kepada korban tindak kekerasan fisik dan psikologis. Dinas Pemberdayaan Perempuan dan Perlindungan Anak Kabupaten Lombok Tengah juga memberikan saran-saran dan solusi agar kejadian tindakan kekerasan terhadap perempuan tidak terulang kembali.

Dinas Pemberdayaan Perempuan dan Perlindungan Anak Kabupaten Lombok Tengah dalam melakukan tugasnya sebagai fasilitator juga melihat kebutuhan korban tindak kekerasan terhadap perempuan yang dibutuhkan, untuk membantu korban menyelesaikan dan menangani tindak kekerasan yang dirasakan oleh korban dan memberikan bantuan yang menjadi kebutuhan utama korban untuk dibantu oleh Dinas Pemberdayaan Perempuan dan Perlindungan Anak Kabupaten Lombok Tengah melalui bentuk fasilitator yang diberikan,dan semua itu perlu didukung oleh sarana dan prasarana yang baik yang diberikan oleh Dinas Pemberdayaan dan Perlindungan Anak Kabupaten Lombok Tengah. 
Selain memberikan saran dan semangat terhadap korban perempuan yang mengalami tindakan kekerasan fisik dan mental tentu harus di sembuhkan secara fisik dan mental. Untuk itu Dinas Pemberdayaan perempuan dan perlindungan Anak Kabupaten Lombok Tengah juga memberikan bimbingan konseling terhadap para korban perempuan tindakan kekerasan baik itu kekerasan dalam rumah tangga maupun dan lain sebagainya. Seperti yang di ungkapkan kepala seksi pemberdayaan perempuan bahwa: "Dinas Pemberdayaan perempuan dan perlindungan Anak Kabupaten Lombok Tengah memberikan bimbingan konseling untuk memperbaiki mental korban. Kami memiiki 4 tenaga pembimbing 2 dari psikolog dan 2 dari advokasi untuk memberikan bantuan hukum pada korban yang mengalami tindakan kekerasan agar mendapatkan bantuan secara mental, fisik dan hukum, agar pelaku tindakan kekerasan juga bisa di proses sesuai peraturan hukum yang berlaku sehingga pelaku mendapatkan efek jera. Sedangkan korban bisa sembuh secara fisik dan mental dari tindakan kekerasan tersebut"

Dari data yang diperoleh dilapangan dapat di ketahui bahwa selain sebagai fasilitator Dinas Pemberdayaan perempuan dan perlindungan Anak Kabupaten Lombok Tengah juga memberikan bimbingan konseling terhadap para korban perempuan kekerasan fisik dan mental di Kabupaten Lombok Tengah. Dinas Pemberdayaan perempuan dan perlindungan Anak Kabupaten Lombok Tengah memiliki 4 tenaga pembimbing 2 dari psikolog intuk menyembuhkan mental dan dua dari advokasi untuk memberikan bantuan hukum pada korban yang mengalami tindakan kekerasan agar mendapatkan bantuan secara mental, fisik dan hukum, agar pelaku tindakan kekerasan juga bisa di proses sesuai peraturan hukum yang berlaku sehingga pelaku mendapatkan efek jera. Sedangkan korban bisa sembuh secara fisik dan mental dari tindakan kekerasan tersebut.

Pada tahun 2015 kekerasan terhadap perempuan yang paling banyak dialami korban kekerasan terhadap perempuan adalah kekerasan fisik 10 kasus dan pada tahun 2016 adalah penelantaran yang dialami oleh korban ada 7 kasus dan pada semester pertama tahun 2017 kekerasan fisik dan kekerasan psikis yang paling banyak dialami oleh korban kekerasan terhadap perempuan yang masing-masing ada 7 kasus dan dilihat dari jumlah data kasus kekerasan terhadap perempuan yang telah ditangani oleh Dinas Pemberdayaan Perempuan dan Perlindungan Anak Kabupaten Lombok Tengah.

Peran dari Dinas Pemberdayaan Perempuan dan Perlindungan Anak Kabupaten Lombok Tengah berjalan dengan baik dengan semakin banyaknya korban yang telah diakomodir untuk ditangani dan bukan berarti peningkatan jumlah kekerasan terhadap 
perempuan berefek negatif tetapi merupakan bentuk semakin sadarnya masyarakat untuk melaporkan kekerasan terhadap perempuan yang terjadi ini bukan berarti tidak jalannya peran dari Dinas Pemberdayaan Perempuan dan Perlindungan Anak tetapi bentuk dari sadarnya masyarakat untuk melapor dari hasil penyuluhan dan sosialisasi dari Dinas Pemberdayaan Perempuan dan Perlindungan Anak di Kabupaten Lombok Tengah namun tetap diharapkan agar angka kekerasan terhadap perempuan mengalami penurunan dikemudian hari.

Dalam menangani kekerasan terhadap perempuan Dinas Pemberdayan Perempuan dan Perlindungan Anak di Kabupaten Lombok Tengah menjadi konselor dalam menangani kekerasan terhadap perempuan dalam melakukaan konseling kepada korban tindak kekerasan terhadap perempuan, Konseling adalah proses pemberian bantuan yang dilakukan oleh seorang ahli yang disebut Konselor/pembimbing kepada individu yang mengalami suatu masalah yang bermuara pada teratasinya masalah yang dihadapi klien, umumnya konseling berasal dari pendekatan humanistik dan berpusat pada klien, konselor juga berhubungan dengan permasalahan sosial, budaya, dan perkembangan selain permasalahan yang berkaitan dengan fisik, emosi, dan kelainan mental.

Dalam hal ini konseling melihat kliennya sebagai seorang yang tidak mempunyai kelainan secara patologis dan juga konseling merupakan pertemuan antara konselor dengan kliennya yang memungkinnya terjadinya dialog dan bukannya pemberian terapi atau perawatan (Treatment) selain itu konseling juga mendorong terjadinya penyelesaian masalah oleh diri klien sendiri dan dalam hal ini Dinas Pemberdayaan Perempuan dan Perlindungan Anak Kabupaten Lombok Tengah sebagai pemberi layanan konseling yang memberikan layanan dan fasilitas konseling untuk Korban kekrasan terhadap perempuan untuk mendapatkan konseling.

Konseling untuk penanganan kekerasan terhadap perempuan di Dinas Pemberdayaan Perempuan dan Perlindungan Anak bahwa korban kekerasan perlu untuk diberikan konseling atau nasehat terkait kekerasan karena dari konseling tersebutlah korban kekerasan dapat mencurahkan keresahannya dan apa yang diinginkannya untuk menyelesaikan masalahnya serta mengurangi beban pikirannya karena sudah disampaikan kepada konselor.

Dinas Pemberdayaan Perempuan dan Perlindungan Anak Kabupaten Lombok Tengah dapat mengetahuai masalah dari koraban dari hasil bimbingan konseling tersebut dan apa yang diinginkan oleh korban kekerasan untuk selanjutnya ditindak lanjuti untuk selanjutnya diarahkan kemana apa yang diinginkan oleh korban kekerasan terhadap perempuan. Semua korban kekerasan terhadap perempuan perlu diberikan konseling oleh Dinas Pemberdayaan 
Perempuan dan Perlindungan Anak Kabupaten Lombok Tengah sebagai konselor dalam memberikan konseling memiliki kegunaan untuk memulihkan trauma yang dialami oleh korban yang dilakukan oleh psikolog dan melakukan pendampingan hukum yang dilakukan oleh tim hukum serta bimbingan kerohanian dan untuk memulihkan trauma.

Dinas Pemberdayaan Perempuan dan perlindungan anak Kabupaten Lombok Tengah juga melaksanakan mediasi terhadap para korban terutama memberikan pemahaman bahwa tindakan kekerasan terhadap perempuan dalam bentuk fisi dan psikologis merupakan tindakan melawan hukum dan bisa di penjara. Dalam melakukan mediasi Dinas Pemberdayaan Perempuan dan perlindungan anak Kabupaten Lombok Tengah melakukan sosialisasi kepada masyarakat Kabupaten Lombok Tengah bahwa melakukan tindakan kekerasan terhadap perempuan adalah tindakan kesejahatan melawan hukum. .

Dinas Pemberdayaan Perempuan dan Perlindungan Anak (DP2PA) Kabupaten Lombok Tengah sebagai Advokator dalam melakukan Advokasi ini juga membutuhkan bantuan dari beberapa pihak atau melibatkan serta melakukan koordinasi dengan instansi lain demi melancarkan proses penyelesaian permasalahan kekerasan yang dihadapi oleh korban kekersan terhadap perempuan agar dapat diselesaikan dengan lancar. Dinas Pemberdayaan Perempuan dan Perlindungan Anak (DP2PA) sebagai Advokator memberikan bantuan advokasi kepada korban kekerasan terhadap perempuan dengan memberikan bantuan pendampingan hukum dari pelaporan, penyelidikan, pemeriksaan hingga kekepolisian dan pengadilan dengan di dampingi oleh advokat dari tim advokasi Dinas Pemberdayaan Perempuan dan Perlindungan Anak hingga kasus tersebut selesai.

Dari data yang diperoleh dilapangan maka dapat disimpulkan bahwa Peran Dinas Pemberdayaan Perempuan dan Perlindungan Anak Kabupaten Lombok Tengah adalah melaksanakan tugas dan fungsi sebagai fasilitator, mediator, konseling dan bantuan advokasi kepada korban perempuan yang mengalami tindakan kekerasan fisik dan psikis. Selain itu juga memberikan sosialisasi kepada masyarakat Kabupaten Lombok Tengah untuk tidak melakukan tindakan kekerasan terhadap perempuan, karena apabila melakukan tindakan tersebut siap-siap untuk masuk penjara karena termasuk melakukan tindakan kejahatan yang melanggar peraturan perundang-undangan. 


\section{PENUTUP}

Dinas Pemberdayaan Perempuan dan Perlindungan Anak memiliki Tugas Pokok dan fungsi sesuai Peraturan Bupati Lombok Tengah Nomor 4 Tahun 2016 Tentang Penjabaran Tugas, Fungsi dan Tata Kerja Struktur Organisasi Lembaga Teknis daerah pada paragraf 2 pasal 49, dimana Dinas Pemberdayaan Perempuan dan Perlindungan Anak Kabupaten Lombok Tengah merupakan unsur pendukung yang mempunyai tugas pokok Dinas mempunyai tugas membantu Bupati melaksanakan urusan pemerintahan konkuren bidang pemberdayaan perempuan dan perlindungan anak dan bidang pemberdayaan masyarakat dan desa yang menjadi kewenangan Pemerintah Daerah dan tugas pembantuan sesuai dengan ketentuan peraturan perundangundangan dan dinas dipimpin oleh Kepala Dinas yang berkedudukan di bawah dan bertanggung jawab kepada Bupati melalui Sekertaris Daerah.

Dinas Pemberdayaan Perempuan dan Perlindungan Anak Kabupaten Lombok Tengah melaksanakan peran sesuai dengan tugas pokok dan fungsi serta kewenangannya berdasarkan peraturan yang berlaku salahsatunya memberikan pendampingan, semangat dan saran kepada korban tindak kekerasan fisik dan psikologis. Dinas Pemberdayaan Perempuan dan Perlindungan Anak Kabupaten Lombok Tengah juga memberikan saran- saran dan solusi agar kejadian tindakan kekerasan terhadap perempuan tidak terulang kembali.

Dinas Pemberdayaan Perempuan dan Perlindungan Anak Kabupaten Lombok Tengah dalam melakukan tugasnya sebagai fasilitator juga melihat kebutuhan korban tindak kekerasan terhadap perempuan yang dibutuhkan, untuk membantu korban menyelesaikan dan menangani tindak kekerasan yang dirasakan oleh korban dan memberikan bantuan yang menjadi kebutuhan utama korban untuk dibantu oleh Dinas Pemberdayaan Perempuan dan Perlindungan Anak Kabupaten Lombok Tengah melalui bentuk fasilitator yang diberikan,dan semua itu perlu didukung oleh sarana dan prasarana yang baik yang diberikan oleh Dinas Pemberdayaan dan Perlindungan Anak Kabupaten Lombok Tengah.

Dinas Pemberdayaan Perempuan dan Perlindungan Anak Kabupaten Lombok Tengah adalah melaksanakan tugas dan fungsi sebagai fasilitator, mediator, konseling dan bantuan advokasi kepada korban perempuan yang mengalami tindakan kekerasan fisik dan psikis. Selain itu juga memberikan sosialisasi kepada masyarakat Kabupaten Lombok Tengah untuk tidak melakukan tindakan kekerasan terhadap perempuan, karena apabila melakukan tindakan tersebut siap-siap untuk masuk penjara karena termasuk melakukan tindakan kejahatan yang melanggar peraturan perundang-undangan. 
1. Perempuan yang mengalami tindakan kekerasan harus segera melapor apabila mendapatkan kekerasan dalam rumah tangga baik fisik maupun psikis agar bisa di proses sesuai dengan aturan dan undang-undang yang berlaku.

2. Perlunya Dinas Pemberdayaan Perempuan dan Perlindungan Anak (DP2PA) Kota Samarinda sebagai Konselor untuk melakukan penambahan personil Konselor terutama Konselor Kerohanian untuk korban yang beragama Non Muslim yang belum tersedia bisa dengan cara berkerja sama dengan pihak Departemen Agama untuk menyediakan Konselor Kerohanian agar dapat mengakomodir semua korban tindak kekerasan yang sangat membutuhkan bantuan dari Konselor Kerohanian.

3. Karena Dinas Pemberdayaan Perempuan dan Perlindungan Anak (DP2PA) Kabupaten Lombok Tengah sebagai mediator disini merupakan sebagai pihak ketiga yang netral dalam menangani dan membantu menyelesaikan kasus oleh karena itu disarankan agar dalam mediasi dapat melakukan pendekatan yang lebih dan meyakinkan pelaku dan korban kekerasan atau kedua belah pihak yang berseteru dalam perebutan hak asuh anak karena perceraian untuk dapat datang saat mediasi dan Dinas Pemberdayaan Perempuan dan Perlindungan Anak perlu menghadirkan konsultan perkawinan dan psikolog dalam upaya mediasi supaya dapat menasehati untuk menemukan jalan terbaik dan kata sepakat yang baik bagi kedua belah pihak.

\section{DAFTAR PUSTAKA}

Adi, Rukmanto, Isbandi. 1994 Psikologi, Pekerjaan Sosial dan Ilmu Kesejahteraan Sosial Dasar-dasar Pemikiran. PT Raja Grafindo Persada: Jakarta.

Bagong, dkk, 2000. Krisis dan Child. Surabaya: Airlangga University Press.

Bagong, Suyanto J. Dwi Narwoko. 2004. Sosiologi Teks Pengantar Terapan. Jakarta: Kencana Media Group.

Bimo Walgito. (2004), Pengantar Psikologi Umum. Jakarta: Penerbit Andi.

Corey, G (1984) Issues \& Etnics In The Helping Professions (2 Edition). Monterey, California: Brooks/Cole Publishing Company.

Corey, Gerald. 1991. Theory and Practice of Conseling and Psycho Therapy 4 Edition.Pacific-Grove Publishing Company California.

Dzuhayatin, Siti Ruhaini dan Yuarsi, Susi Eja. 2002. Kekerasan terhadap Perempuan di Ruang Publik. Yogyakarta: Ford Foundation. 
Journal of Government and Politics (JGOP) Vol. 1 No. 2 Desember 2019 Hal. 112-124

Gibson. 2003. Organisasi, Jilid 1, Terjemahan Darkasih. Erlangga: Jakarta Hasbianto, Elli N. (1996). Kekerasan Dalam Rumah Tangga. Potret Muram Kehidupan. Insano (Jones), 2004, Bimbingan dan Konseling, Ciputat Press, Jakarta.

Levinso dan Soekanto. 2009. Peranan, Edisi baru, Rajawali Pers: Jakarta.

Rivai, Veithzal. 2006. Kepemimpinan dan Perilaku Organisasi. Raja Grafind :Jakarta.

Zulkifli, Adam Idris, Melati Dama "Peran Dinas Pemberdayaan Perempuan Dan Perlindungan Anak Dalam Menangani Kekerasan Terhadap Perempuan Di Kota Samarinda" Unmul: 2017

https://id.wikipedia.org/wiki/Kabupaten_Lombok_Tengah

http://lomboktengahkab.go.id/demografi/ 